\title{
Teachers' perceptions of the influence of learners' undisciplined behaviour on their working life and of the support of role-players
}

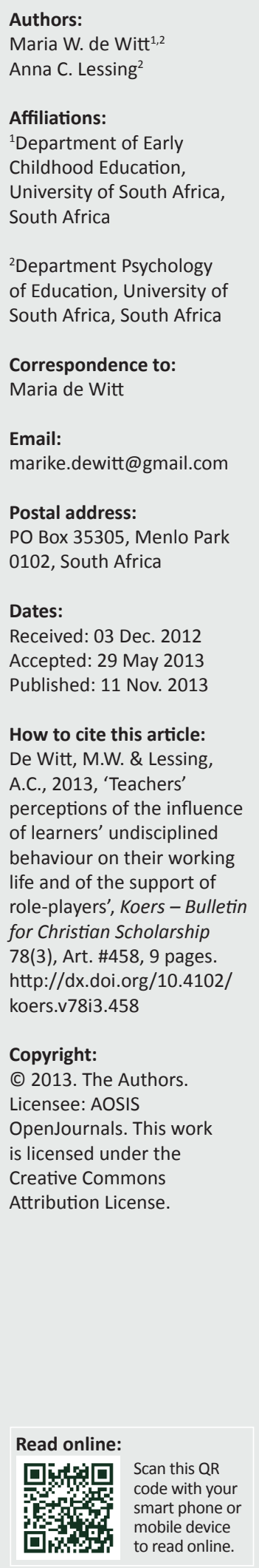

Authors:

Maria W. de Witt

Affiliations: University of South Africa, South Africa

Department Psychology of Education, University of

Correspondence to:

Email:

Postal address:

PO Box 35305, Menlo Park

Dates:

Received: 03 Dec. 2012

Accepted: 29 May 2013

How to cite this article:

De Witt, M.W. \& Lessing

of learners' undisciplined

behaviour on their workin

for Christian Scholarship

Art. \#458, 9 pages.

http://dx.doi.org/10.4102/

Copyright:

(C) 2013. The Authors.

is licensed under the

Creative Commons

Attribution License.
Unacceptable behaviour by learners in South African schools is a major concern for all stakeholders in the teaching profession. This explains the increased interest in the role and responsibility of teachers in managing problem behaviour and the effect of this behaviour on educators' quality of life in the workplace. This research posed the following questions: Does inappropriate student behaviour affect teachers' working life, and if so, to what extent? Is the prevalence of undisciplined behaviour higher amongst boys and in multicultural schools? What is the influence of learners' disruptive behaviour on teachers? How do teachers experience support from role-players? A questionnaire was used to obtain information for answering these questions. Although the findings of this research indicated that not all teachers experience excessive emotional reactions that may contribute to stress, it appeared that undisciplined behaviour was the source of irritation, made demands on teachers' temper and caused aggression. The majority of teachers reported that they enjoyed sufficient support from the school's governing body, but they were not satisfied with the support from parents and the department of education. In spite of the high percentage of teachers who indicated that undisciplined behaviour impacted on their job satisfaction, the majority do not consider leaving the teaching profession.

Onderwysers se persepsies oor die invloed van ongedissiplineerde leerdergedrag op hulle werksituasie en oor die ondersteuning van rolspelers. Onaanvaarbare leerdergedrag in Suid-Afrikaanse skole is ' $n$ ernstige bron van kommer vir alle betrokkenes in die onderwys. Dit verklaar die toenemende belangstelling in die rol en verantwoordelikheid van onderwysers in die hantering van probleemgedrag en die uitwerking van sodanige gedrag op opvoeders se lewensgehalte in hulle werksituasie. Hierdie navorsing het die volgende vrae gestel: Beïnvloed ontwrigtende leerdergedrag onderwysers se werksituasie en indien wel, in watter mate? Is die voorkoms van ongedissiplineerde gedrag hoër onder seuns en in multikulturele skole? Wat is die invloed van onaanvaarbare leerdergedrag op onderwysers? Hoe ervaar onderwysers die ondersteuning van rolspelers? 'n Vraelys is gebruik om inligting in te samel om die bostaande vrae te beantwoord. Hierdie navorsing het getoon dat sommige onderwysers nie oormatige emosionele reaksies ervaar wat tot stres kan bydra nie, maar dat leerders se ongedissiplineerde gedrag irritasie veroorsaak, eise aan onderwysers se humeur stel en aggressie uitlok. Die meerderheid onderwysers het aangedui dat hulle voldoende ondersteuning van hulle skool se beheerliggaam ontvang, maar van die onderwysers was nie tevrede met die ondersteuning van ouers en die onderwysdepartement nie. Ten spyte van die hoë persentasie onderwysers wat aangedui het dat ongedissiplineerde gedrag 'n impak het op hulle werksbevrediging, oorweeg die meerderheid van hierdie onderwysers dit nie om die onderwysprofessie te verlaat nie.

\section{Introduction}

Educationalists are complaining about the increase of behavioural problems in South African schools. Role players in education ask questions about the causes of these problems, and the answers point to, amongst other factors, the numerous changes in the educational system since 1994 (Lessing \& De Witt 2010:21). One of the major stressors indicated by the teachers in a preliminary investigation was their limited teaching experience at multicultural schools. Prior to 1994, teachers were predominantly employed in monocultural schools, which in most cases had been converted into multicultural schools. This situation could contribute to teacher stress. In their study of American schools, Truscott et al. (2012:65) established the following: 'Many schools are ill-prepared to meet new demands ... and the system has to change and adapt to evolving student demographics, political climates, educational policies, and economic contexts.' 
Within the framework of a Christian perspective, the tolerance of all groups gained considerable prominence in the new educational dispensation. From discussions with teachers, it transpired that they find it difficult to deal with the lack of respect and responsibility, disobedience, aggression and the rejection of authority demonstrated by some of the learners in their classroom. Low-impact behaviour, such as intermittent talking, not listening and not paying attention, as well as unruly out-of-desk behaviour in the classroom, was found to be largely responsible for teachers' frustration and stress (Axup \& Gersch 2008:145; Donald, Lazarus \& Lolwana 1997:12; Ellenwood 2007:20; Ertesvåg \& Vaaland 2007:713; Oosthuizen 2006:12).

Internationally, it also seems that an increase in disorderly behaviour in schools constitutes a significant problem (Pšunder 2005:335). Not only in secondary schools but also in the intermediate and foundation phases, learners exhibit problem behaviour varying from misbehaving to social defiance and even social delinquency.

There is a growing interest in the role and responsibility of teachers in managing problem behaviour and its effects on the educator's quality of life in the workplace. Morrison Bennett and Bratton (2011:200) refer to conscious discipline as teachers aim 'to build character, relationships and social skills'.

The increase in learners' misbehaviour at school is one of the essential areas that need to be addressed by parents, governing bodies and school-management teams. The extent of this phenomenon is apparent from the following statement by the South African Teachers Union (SATU) (2009):

It is the undeniable responsibility of parents to send the learners to schools in the knowledge that learners must comply with the reasonable codes of conduct, and to also realise the consequences of not obeying with the school rules. (p. 1)

Adhering to a positive code of conduct implies principles such as self-control, self-discipline and self-direction, all of which are educational concepts strongly related to Christian values and grounded in the Christian doctrine. The Christian faith underlies the life and worldview of the authors of this article. From this perspective, when learners do not comply with school rules, the results can be demoralising for the teachers as they are the ones who pay the price in terms of their quality of life in the workplace.

The following questions were considered in this research study:

- What influence does the disruptive behaviour of learners have on teachers?

- Does inappropriate learner behaviour affect the working life of teachers, and if so, how?

- Do teachers consider leaving the teaching profession?

- How do teachers experience support from role-players, including the parents, and could teachers be better supported within the school system?
- What are teachers' views on the effectiveness of various disciplinary strategies?

Derived from these research questions, the following null hypothesis was formulated:

- Inappropriate learning behaviour does not affect the working life of teachers.

\section{Conceptualisation}

Based on their personal lives and worldviews, teachers hold different views with regard to the nature of disciplined and undisciplined behaviour and of disciplinary problems. In a qualitative study, Joubert and Serakwane (2009:127-128) found that teachers interpret discipline as the development of a moral character, displaying control over learners, the prevention of undisciplined behaviour, corrective measures, self-discipline and even punishment. Scarpaci (2007:111112) raised the question whether behavioural problems exist only when behaviour impinges negatively on learning and whether controlling classroom behaviour is always aimed at facilitating learning and encouraging self-discipline. It appears that, when discipline is equalled to maintaining order in the classroom and to the development of selfdiscipline, behaviour that does not comply with order in the classroom is categorised as undisciplined behaviour (Lessing \& De Witt 2010:25).

The learner who manifests undisciplined behaviour such as ignoring the teacher not only shows disrespect towards the teacher but also disregards the teacher's position of authority, which is a biblical command. It often happens that the undisciplined behaviour of the learner contributes to an emotional reaction or outburst by the teacher (Oosthuizen 2006:12). This may cause an unhealthy and negative classroom atmosphere, impede teaching, contribute to an unsafe learning environment and subject the teacher to unnecessary challenges and stress (Ertesvåg \& Vaaland 2007:713; Schaubman, Stetson \& Plog 2011:72). In a study by Hastings (2005:210), staff reported a range of negative reactions to learners' behavioural problems, naming sadness, fear, anger and frustration as typical responses.

The proven relationship between severe behavioural problems and the staff's psychological well-being may be an indication that negative emotional reactions increase the impact of problematic learner behaviour on staff, making them prone to stress and burnout (Axup \& Gersch 2008:145; Hastings 2005:207; Klusmann et al. 2008:146). Studies by Davis and Sumara (1997) and Bibou-Nakou et al. (2000, cited in Pšunder 2005:337) confirmed that teachers' beliefs about behavioural problems have a major impact on how they understand and respond to events in the classroom (Pšunder 2005:337). A vicious circle develops when staff behaviour affects learners' behaviour and vice versa, for learners' behavioural problems also affect staff behaviour (Hastings 2005:209). The whole process causes negative emotional reactions and impacts on staff's psychological well-being (Baron \& Kenny 1986). The question arises whether the Christian principles of tolerance, 
respect and love, manifesting in self-love and love for others, could prevent this cycle. When individuals treat one another with tolerance, respect and love, these qualities can be expected to be reflected in the other person's behaviour.

Teachers dealing with the issue of problematic behaviour in the classroom will confirm that they spend so much time on the few learners who exhibit disruptive and offtask behaviour that they are less available for academic instruction to the remainder of the learners (those not involved in problem behaviour) (Conroy et al. 2008:25). This situation puts teachers under stress as dedicated teachers want to be available for all learners and assist them to reach optimal development.

To ensure the best functioning of a school, management teams should place the psychosocial well-being of their staff high on their agenda. For maintaining a positive environment in a school, self-fullfilled educators, demonstating high levels of energy and resilience should form the workforce of a school, and should be a priority for maintaining a positive environment. Reyes et al. (2012:700) emphasise the importance of the emotional climate in the classroom. This is a contributing factor to a positive school environment, which results from 'teachers who are sensitive to students' needs ... and teacher-student relationships that are warm, caring, nurturing and congenial' (Siltaloppia, Kinnunena \& Feldt 2009:334). De Witt and Lessing (2012:429) state that self-fulfilled teachers should demonstrate dedication, manifesting in a sense of significance, enthusiasm, inspiration, pride and the facing of challenges.

Teachers need to understand and deal with problem behaviour in schools to ensure a more pleasant and less stressful work environment. Truscott et al. (2012:64) suggest exceptional professional learning (EPL) to help educators 'identify, implement, adapt, and sustain effective practices'. Research indicates that the confidence of staff who deal with behavioural problems improves after they received specialised training in classroom management, as the gained knowledge enables them to improve their management of learner behaviour (McDonnell 1997 in Hastings 2005:213). This needs to be a priority for staff training and support, especially in situations where job satisfaction and the psychological well-being of staff are low (McKenzie et al. 2001 cited in Hastings 2005:213). Well-planned and wellmanaged preventive and corrective approaches may help to reduce disciplinary problems in schools (Pšunder 2005:336) whilst Schaubman et al. (2011:72) emphasise the importance of training in Collaborative Problem Solving (CPS) as it enables teachers to understand the underlying reasons for learners' unacceptable behaviour.

Apart from classroom management, it is essential that teachers attend to their personal health and take measures to combat stress. Kaspereen (2012:246) emphasises the importance of identifying stressors and applying relaxation techniques to lower stress levels.
Recent research also points out that teachers, in maintaining disciplined behaviour in the classroom, need to move away from punitive discipline and strive to develop learners' selfdiscipline (Biemond, Van der Walt \& Wolhuter 2010:65; Heystek 2010:48; Lessing \& De Witt 2010:21; Oosthuizen 2006:48). According to Gomez and Ang (2007:98), schools can provide positive opportunities to ensure positive behaviour and self-fulfilled teachers. These opportunities can promote positive development and act as protective factors in the school environment. Suggested factors that will promote a positive atmosphere in schools include cooperation between all role-players, a positive class atmosphere, appreciation from superiors and parents and the cooperation of learners. However, the role played by the teacher cannot be overestimated. A positive adult presence can be established by acknowledging desirable learner behaviour, offering concrete feedback and praise for milestone events and being sensitive to signs of difficulty in learners' lives (Elias et al. 2003 cited in Gomez \& Ang 2007:98). Gomez and Ang (2007:98) also advocate listening to learners non-judgementally, providing emotional support, acknowledging their work and appreciating them as individuals, all of which are conducive to a positive learning environment.

Strategies to enhance a positive learning environment include the following:

- class-wide interventions when implementing positive behaviour

- close class supervision and monitoring

- compiling classroom rules

- using praise; providing feedback and error correction

- monitoring learner progress (Conroy et al. 2008:25; Franzen \& Kamps 2008:151).

Activities to discipline learners should occur in a caring, loving relationship between the learner and the educator. Ziunhia, Hatziharistos and Emmanouel (2003:299) postulate that there is a strong correlation between strategies emphasising intrinsic reasons for maintaining good behaviour and responsibility amongst learners and reasons for behaving appropriately, which would contribute to a positive school atmosphere. Nevertheless, teachers find themselves in a stressful work environment, and they should develop coping skills to deal with problematic learner behaviour.

To establish the impact of learners' behaviour on the working life of educators, the following issues should be examined: What is the effect of learners' behavioural problems on the social and emotional life of teachers, and do these problems impact on teachers' quality of life? Do teachers know what the appropriate legislation entails, and do they experience support from educational departments in managing learners' behaviour? Do teachers perceive that other role-players in the system offer support for handling learners' behavioural problems?

\section{Research method and process}

A mixed method was followed in the research which led to this article. Qualitative research was used in a preliminary 
investigation to explore the nature of disciplinary problems experienced by teachers (Creswell 2002:86; Jesson \& Lacey 2006:139; Page \& Meyer 2003:22), and the qualitative pilot study was followed up by quantitative research using a questionnaire to determine related disciplinary issues that influence the teacher's working life.

This article reflects on a section of the research done by the authors on disciplinary problems in schools where SATU is the dominant trade union. The overarching research process comprised distinct phases of data collection: a pilot study involving teachers doing postgraduate studies, a literature study of researchers' insights into the field of study, the findings of other researchers on the topic as well as an empirical investigation into the teachers' views on different aspects regarding discipline in the particular schools. Twenty postgraduate student teachers in a focus group were requested to list unacceptable learner behaviour that they had experienced in their classrooms. The information obtained from these teachers was used to guide the literature study, which served (as suggested by Gall, Gall \& Borg 2005:28) as a basis for the development of a questionnaire. This included closed (Section A and B) as well as open-ended questions (Section C) on teachers' views concerning undisciplined behaviour.

Section A (17 questions) was aimed at gathering biographical and contextual information whilst section B (135 questions) focused on the nature and prevalence of undisciplined behaviour as perceived by the participating teachers. Section C, which will not be dealt with in this article, consisted of 20 open-ended questions to determine teachers' views regarding the influence of disciplinary problems on their working life as well as the possible causes of disciplinary problems, the maintenance of discipline and teacher support from the different role-players.

To ensure the quality of the research, the expertise of an information technology (IT) specialist was acquired, and a statistician compiled the computerised version of the questionnaire as suggested by McMillan and Schumacher (2006:197). The questionnaire was completed electronically by school principals, Heads of Departments and Post Level 1 (young) staff members in the respective school phases at various schools.

The researchers adhered to the required ethical measures: Confidentiality was ensured, and specific attention was paid to the participants' rights. The South African Teachers Union was responsible for the distribution and collection of the questionnaires, and schools were not obliged to participate. An extensive report on the research was submitted to the South African Teachers Union. This was followed by a workshop for members of the Union to discuss possible teacher support with a view to reducing problems that may contribute to stress.

The aim of the empirical investigation reflected in this article is imbedded in questions to establish the following: What is teachers' perception of the influence of learners' undisciplined behaviour on their working life, and how do they perceive the support of the role-players?

\section{The research context and sample}

The research population for this study consisted of principals and senior and novice teachers affiliated with the South African Teachers Union at 350 primary and secondary schools. The Union wished to obtain a better understanding of teachers' needs in the participating schools and selected about $12 \%$ of the affiliated schools. These comprised urban, suburban, multicultural, English-medium, Afrikaansmedium, parallel-medium and dual-medium schools. It also included high schools, primary schools, special-education schools as well as technical and agricultural schools. The SATU secretaries in the respective provinces were requested to compile a list with a selection of schools. The study relied heavily on the cooperation of schools affiliated with SATU. In order to achieve a representative and reliable response, it was important for participants to realise the need for such a study, and SMSs and emails were sent out on several occasions, reminding participants to complete the questionnaires. Table 1 indicates the distribution of participating schools in the respective provinces.

To ensure reliability in the design of the research method, it was important that the research model would measure the correct variables. The questionnaires were sent out electronically by means of emails. This was done to ensure that the questionnaires would be completed by the correct recipients and that the information obtained would be relevant. The questions in section B addressing the working life of teachers were set up to elicit answers in a closed format, which would result in a better statistical analysis. As already mentioned, section $C$ of the questionnaire comprised openended questions, which will not be addressed in this article.

The reliability and validity of measures undertaken in a study partly reflect the researchers' level of confidence in the results yielded by the research design (Page \& Meyer 2003:84). Since there was no control group for this investigation, the only internal validity factor influencing the research was whether the questionnaire measured the variables correctly. The reliability of the data was improved by dispatching the questionnaires via email rather than posting or faxing them.

\section{Data-collection methods}

For purposes of triangulation, preliminary research was conducted, and the literature was reviewed in order to

TABLE 1: Distribution of questionnaires per province.

\begin{tabular}{ll}
\hline South African Province & Schools \\
\hline Gauteng & 70 \\
KwaZulu-Natal & 20 \\
Limpopo & 20 \\
Mpumalanga & 25 \\
North West & 30 \\
Free State & 60 \\
Northern Cape & 25 \\
Eastern Cape & 35 \\
Western Cape & 50 \\
\hline Total & $\mathbf{3 3 5}$ \\
\hline
\end{tabular}


grasp the key concepts. A questionnaire was then developed and piloted prior to implementation. The general strategy was to use a theoretical framework as a background to be incorporated in an inductive approach. This strategy was supported by an analytical procedure to scrutinise the data (Gay, Mills \& Airasian 2006:163).

This particular study was of an empirical nature, but it also incorporated aspects of theory testing in order to ensure triangulation, thus adding to the validity. As questionnaires were dispatched electronically, the responses were returned as numerical data that would be ready for statistical analysis (Saunders, Lewis \& Thornhill 2003:284). Data were collected, encoded, processed and analysed. The responses to the stated themes were collected via personal and impersonal means.

As the racial composition of the schools was also established in the questionnaire, it revealed the following data:

- $66 \%$ White people

- $23 \%$ Black people

- $9 \%$ people of mixed-race

- $2 \%$ Indian people.

A number of 62242 learners attended the schools that responded.

\section{Focus of the discussion in terms of the findings}

From the comprehensive study regarding discipline, only responses pertaining to aspects that might influence the teacher's life world were selected as a source for reflection. The focus of this article is on:

- Perceptions of teachers about the influence that learner groups' cultural identity may have on discipline.

- Factors influencing the behaviour of learners.

- The effect of learners' undisciplined behaviour on the emotional and social life of teachers.

- Support from other role-players in managing learners' behaviour.

- Whether teachers considered leaving the teaching profession due to stress.

- Teachers' views on the effectiveness of corporal punishment for managing behavioural problems.

\section{Non-parametric correlations (Spearman's Rho)}

In investigating the composition of the schools in question, particular attention was paid to boys as well as to second- language and home-language learners (Table 2a). To establish whether there was any relationship between the composition of the learner group and the occurrence and consequences of behavioural problems, Spearman's correlation coefficient (Rho) was calculated. This method is used with ordinal data where data are crudely measured, but the ordering of the data is correct. The Spearman coefficient uses the ranks for the data to calculate the coefficient with a value between -1 and 1, with -1 indicating a perfect straight-line relationship with a negative slope, and +1 indicating a perfect positive straight-line relationship (Page \& Meyer 2003:154). Thus, a positive or negative sign associated with the Spearman correlation indicates whether respondents generally agree or disagree with the statement whereas the value gives an indication of the degree to which they agree.

The $P$-value is defined as the 'probability of obtaining results no more supportive of $\mathrm{H} 0$ than those found in the sample, when the null hypothesis is true' (Page \& Meyer 2003:167) (An AP-value of less than 5\% indicates a high unlikelihood that the null hypothesis is true; therefore the null hypothesis can be rejected and it is called a significant test result). Should the $P$-value be above $5 \%$, the null hypothesis cannot be rejected and is therefore termed a non-significant test result (Page \& Meyer 2003:167). Consequently, the $P$-value is an indication of the likelihood that a null hypothesis is possible, and it is expressed as a percentage. The correlation coefficient is an indication of the strength of the dependency between a school's cultural composition and the behavioural problems experienced by teachers. According to Table 2a, all of the values are meaningful, and evidently teachers experience that the more diverse the cultural composition of schools, the more the behavioural problems. The Christian principle of tolerance can play an important role in the teacher's mindset, determining how they handle and accept the differences in behaviour of learners from diverse cultural groups.

According to Table $2 \mathrm{~b}$, the correlation between the percentage of boys and behavioural problems is not meaningful. This indicates that teachers do not experience that a larger number of boys in a school contributes to more behavioural problems than a smaller number of boys.

\section{Factors influencing the behaviour of learners}

Factors included in the questionnaire that could influence learner behaviour are the following: policy, ignorance of policy on the part of the teachers, legislation and its possible effects and the role of parents in their children's misbehaviour. The findings are shown in Table 3.

TABLE 2a: Correlation between the occurrence of behavioural problems and the composition of the learner group.

\begin{tabular}{|c|c|c|c|c|c|c|}
\hline \multirow[t]{2}{*}{ Correlation coefficient (Spearman's Rho) } & \multicolumn{2}{|c|}{ Boys } & \multicolumn{2}{|c|}{ Second language learners } & \multicolumn{2}{|c|}{ Home language learners (Afrikaans) } \\
\hline & $\begin{array}{l}\text { Correlation } \\
\text { coefficient }\end{array}$ & $P$-value (\%) & $\begin{array}{l}\text { Correlation } \\
\text { coefficient }\end{array}$ & $P$-value (\%) & $\begin{array}{l}\text { Correlation } \\
\text { coefficient }\end{array}$ & $P$-value (\%) \\
\hline Occurrence: low impact & .160 & .073 & .181 & .053 & $-.260 *$ & .004 \\
\hline Occurrence: serious & -.015 & .866 & $.243^{*}$ & .009 & $-.263^{*}$ & .004 \\
\hline Occurrence: aggressive & .000 & .992 & $.285 *$ & .002 & $-.228 * *$ & .012 \\
\hline
\end{tabular}

*, Correlation is significant at the 0.01 level (2-sided)

**, Correlation is significant at the 0.05 level (2-sided) 
TABLE 2b: Correlation between the increase in behavioural problems and composition of the learner group (boys).

\begin{tabular}{|c|c|c|c|c|c|c|}
\hline \multirow{2}{*}{$\begin{array}{l}\text { Correlation coefficient } \\
\text { (Spearman's Rho) }\end{array}$} & \multicolumn{2}{|c|}{ Boys } & \multicolumn{2}{|c|}{ Second language learners } & \multicolumn{2}{|c|}{ Home language learners (Afrikaans) } \\
\hline & Correlation coefficient & $P$-value (\%) & Correlation coefficient & $P$-value (\%) & Correlation coefficient & $P$-value (\%) \\
\hline Occurrence: low impact & .059 & .522 & .158 & .096 & -.125 & .177 \\
\hline Occurrence: challenging & .053 & .559 & $.302 *$ & .001 & $-.311 *$ & .001 \\
\hline Occurrence: serious & -.044 & .628 & $.293^{*}$ & .002 & $-.289^{*}$ & .001 \\
\hline Occurrence: aggressive & .049 & .591 & $.241 *$ & .010 & $-.230 * *$ & .012 \\
\hline
\end{tabular}

*, Correlation is significant at the 0.01 level (2-sided)

$* *$, Correlation is significant at the 0.05 level (2-sided)

TABLE 3: Factors influencing the behaviour of learners.

\begin{tabular}{|c|c|c|c|c|}
\hline Factors influencing the behaviour of learners & Not at all (\%) & To a lesser extent $(\%)$ & To a certain extent $(\%)$ & Definitely (\%) \\
\hline School policy & 52.55 & 32.12 & 13.14 & 2.19 \\
\hline Ignorance of policy & 36.50 & 37.96 & 20.44 & 5.11 \\
\hline Legislation & 13.87 & 16.06 & 33.58 & 36.50 \\
\hline Parents & 2.92 & 12.41 & 45.26 & 39.42 \\
\hline
\end{tabular}

The data in Table 3 indicates that teachers perceive that parents do play a prominent role in the behavioural problems displayed by learners as $84 \%$ of the participants responded accordingly. Regarding the question whether school policy causes behavioural problems, $84.67 \%$ of the participants indicated that it plays no role. The fact that educators perceive parents to be contributing to the misbehaviour of their children is alarming and should be taken up with the parents' association and governing body of the school. The establishment of values, and from our perspective Christian values, is the responsibility of both school and parents. Lessing and De Witt (2010:35) state that the school is responsible for developing a culture of order and discipline in cooperation with the parents and learners with all parties participating, sharing and taking pride in such responsibility.

\section{The effect of learners' behaviour on the emotional life of teachers}

The participants (teachers) were requested to indicate the extent to which learners' behaviour impact on their emotional life and the extent to which it influenced their quality of life. Aspects investigated were depression, irritability, effect on temper, a feeling of withdrawal, aggression, a tendency to cry and impatience.

The information in Table 4 indicates that $64.49 \%$ of the teachers who participated in the study reported that learners' unacceptable behaviour caused irritability with $58.7 \%$ indicating that it influenced their temper. An increase in the occurrence of bad temper amongst teachers is a sign of underlying stress and may, according to Hastings (2005:210), give rise to negative feelings about the teaching profession. According to the life view contained in the Christian doctrine, the fruit of the Spirit includes self-control, which may combat the negative emotions and accompanying stress aroused by learners' negative behaviour. Although less than half of the participants reported their feelings of depression (36.5\%), impatience $(39.85 \%)$ and aggression $(42.34 \%)$ to be the result of learners' undisciplined behaviour, the fact that these feelings are experienced by more than a third of the participants cannot be disregarded.
TABLE 4: The effect of learners' behaviour on the emotional life of teachers.

\begin{tabular}{lll}
\hline Behaviour & No and low impact (\%) & Definite and high impact (\%) \\
\hline Irritability & 35.51 & 64.49 \\
Depression & 63.5 & 36.50 \\
Effect on temper & 41.3 & 58.7 \\
Withdrawal & 80.29 & 19.71 \\
Aggression & 57.66 & 42.34 \\
Tendency to cry & 80.29 & 19.71 \\
Impatience & 60.15 & 39.85 \\
\hline
\end{tabular}

\section{The effect of learners' behaviour on the social life of teachers}

The participants were requested to indicate the extent to which learners' behaviour influenced their social life and the extent to which it impacted on their quality of life. The aspects considered were family life, social life, social interaction, health, quality of life, religious life and job satisfaction.

Although most participants indicated that learners' undisciplined behaviour has a low impact on their family, their social and religious lives, social interaction and their quality of life, it must be borne in mind that almost a third of the teacher corps who participated in the study felt that undisciplined behaviour affected their lives. More than half of the participants $(55.11 \%)$ felt that undisciplined behaviour influenced their health whilst $61.76 \%$ experienced a lack of job satisfaction due to the learners' behaviour. Health and quality of life in the workplace are two markedly important determinants in psychosocial well-being (Axup \& Gersch 2008:145; Hastings 2005:207; Klusmann et al. 2008:146).The results of this investigation imply that more than a third of the participating teachers are not very happy at work.

\section{Support from role-players in managing learners' behaviour}

Responses to the question whether the various role-players, including the governing body, the department of basic education and the parents, supported teachers in managing behavioural problems are reflected in Table 6 .

Most of the respondents $(82.46 \%)$ indicated that the governing bodies of schools offer support in managing 
the behavioural problems of learners in their particular school, but only $27.21 \%$ mentioned receiving support from the various education departments. This finding points toward a significant problem in the education system as the Department of Basic Education is expected to support school-management teams to a much larger extent (De Witt \& Lessing 2012:434). Teacher unions need to inquire into the lack of support from the different departments of education (Gomez \& Ang 2007:98). Of the $69.85 \%$ of teachers who indicated that the school receives support from the parents in disciplining learners, only $18.38 \%$ felt that parents definitely provide such support. From a Christian perspective, norms and value-based education should be duly emphasised in deliberations with parents (Lessing \& De Witt 2010:35; Ziunhia et al. 2003:299). Even in a situation involving the employee and the employer, the principle of respect and cooperation remains a priority.

\section{The option of leaving the teaching profession}

Assuming that teachers experience excessive stress because of disciplinary problems within the school, the question arises whether these teachers might consider leaving the teaching profession as a result. The responses to this question are reflected in Table 7.

In spite of the fact that $61.76 \%$ (see Table 5) of the participants indicated that learners' behaviour has an impact on their job satisfaction, the findings reflected in Table 7 show that $74.22 \%$ of the respondents do not wish to leave the profession. Though it may seem that the majority do not intend to leave, it would be wise to attend to the $25.78 \%$ who have indeed considered leaving the profession. In a country with a crucial shortage of educators (Monama 2012), this figure, together with a high unemployment rate, should be of the highest concern. The seemingly positive outcome of this finding may be attributed to the so-called 'calling to become a teacher'. This principle should be stressed in the recruitment of teachers as the 'calling' aspect contributes to endurance and stability in education. It is also important to alert prospective education students to factors that may cause stress in a teacher's working life.

\section{Corporal punishment in managing behavioural problems}

As corporal punishment was one of the strategies employed to manage behavioural problems in the previous dispensation, this question was included to establish whether teachers' perceptions of the use of corporal punishment had changed. The responses to this question are reflected in Table 8 .

In spite of the fact that teachers are forbidden to execute corporal punishment, $79.2 \%$ of the participants indicated that corporal punishment is effective for managing behavioural problems in schools. This finding should be of prime concern of educational planners, and further research needs to be done regarding the use of corporal punishment. From a Christian perspective, it must be kept in mind that this type of punishment, if implemented at all, should be conducted in a sympathetic way to demonstrate the value of love (Oosthuizen 2006:8-100; Reyes et al. 2012:700). The question
TABLE 5: The social life of the teacher.

\begin{tabular}{lll}
\hline Variable & No and low impact (\%) & Definite and high impact (\%) \\
\hline Family life & 60.58 & 39.42 \\
Social life & 71.02 & 28.98 \\
Social interaction & 82.78 & 37.22 \\
Health & 44.89 & 55.11 \\
Quality of life & 57.97 & 42.03 \\
Religious life & 75.36 & 24.64 \\
Job satisfaction & 38.24 & 61.76 \\
\hline
\end{tabular}

TABLE 6: Support from role-players.

\begin{tabular}{lll}
\hline Role-player & $\begin{array}{l}\text { Not at all plus to a lesser } \\
\text { extent } \mathbf{( \% )}\end{array}$ & $\begin{array}{l}\text { To a certain extent plus } \\
\text { definitely (\%) }\end{array}$ \\
\hline Governing body & 17.54 & 82.46 \\
Department & 72.79 & 27.21 \\
Parents & 30.15 & 69.85 \\
\hline
\end{tabular}

TABLE 7: Teachers considering leaving the teaching profession.

\begin{tabular}{lll}
\hline Decision & $\begin{array}{l}\text { Not at all plus to a lesser } \\
\text { extent } \mathbf{( \% )}\end{array}$ & $\begin{array}{l}\text { To a certain extent plus } \\
\text { definitely }(\mathbf{\%})\end{array}$ \\
\hline Considering leaving & 74.22 & 25.78 \\
\hline
\end{tabular}

TABLE 8: The effectiveness of corporal punishment in managing behavioural problems.

\begin{tabular}{lll}
\hline Corporal punishment & $\begin{array}{l}\text { Not at all plus to a lesser } \\
\text { extent (\%) }\end{array}$ & $\begin{array}{l}\text { To a certain extent plus } \\
\text { definitely (\%) }\end{array}$ \\
\hline $\begin{array}{l}\text { Effectiveness of corporal } \\
\text { punishment }\end{array}$ & 20.89 & 79.2 \\
\hline
\end{tabular}

TABLE 9: Effect of strategies for handling behavioural problems.

\begin{tabular}{lll}
\hline Strategy & $\begin{array}{l}\text { Not at all plus to a lesser } \\
\text { extent (\%) }\end{array}$ & $\begin{array}{l}\text { To a certain extent plus } \\
\text { definitely (\%) }\end{array}$ \\
\hline Teaching strategies & 1.46 & 98.54 \\
Handling of learners & 1.48 & 98.52 \\
Punitive actions & 32.85 & 67.15 \\
Immediate action & 1.48 & 98.52 \\
\hline
\end{tabular}

arises as to whether teachers who feel positive about corporal punishment are still using these punitive measures to maintain discipline in the classroom.

\section{Strategies for handling behavioural problems}

As indicated in the literature study (Hastings 2005:213; Joubert \& Serakwane 2009:127, 128), it appears that teaching strategies play a prominent role in maintaining discipline or preventing behavioural problems in class. Though this article is not focussing on management strategies, it is important to note the effect of managing strategies on the life world of teachers. Therefore teachers need training not only to manage their classrooms but also to manage their stress levels (see Table 9).

Almost all of the participants (more than 98\%) agreed that teaching strategies, the way in which learners are handled and immediate action are the most effective tools to manage behavioural problems. This finding is in accordance with that of Gomez and Ang (2007:98). A high percentage (67.15\%) of the participants viewed punitive actions as effective strategies to deal with behavioural problems. This is in line with the $79.2 \%$ of participants who still regard corporal punishment as the most effective way to maintain discipline. Teaching strategies, the handling of learners and immediate action are 
skills in which beginner teachers need to be trained. It should form part of the planning and needs to be prioritised and implemented by school-management teams.

\section{Conclusion and recommendations}

The overall impression transpiring from the findings is that not all teachers experience excessive emotional reactions that may contribute to stress. However, it is important to note instances of increased irritability and bad temper. More than $50 \%$ of the teachers indicated that they do experience health problems and negative effects on the quality of their working life, which stresses the importance of teachers managing their stress levels. All of these factors undoubtedly influence the psychosocial well-being of teachers (Hastings 2005:210), an issue which should be high on the agenda of schoolmanagement teams. Ways to improve the psychological wellbeing of staff members as well as strategies on how to remain in control should form part of this agenda. Special attention needs to be paid to beginner teachers who are entitled to the support of experienced staff members. It would be advisable for school-management teams to implement stress-relief workshops or programmes in schools, helping staff members to acquire the necessary coping skills. Schools should have a very specific Christian ethos, which should be developed and adhered to by all role-players. The ethos of schools affiliated with SATU is underpinned by Christian values and mothertongue instruction.

Although the majority of respondents in this survey indicated that they do not intend leaving the teaching profession, attention should be paid to the voices of those who admit to being unhappy in their teaching career. We suggest that qualitative research can be conducted to determine the nature of these teachers' unhappiness.

As the findings indicated that schools do not enjoy the support of the Department of Basic Education in managing learners' behavioural problems, the governing bodies and teacher unions should bring the matter to the attention of the relevant authorities. As reflected in this article, parents will also have to contribute as far as their input into and responsibility for their children's behaviour is concerned.

Specialised training in classroom management is described in the literature (McDonnell 1997 cited in Hastings 2005:213) as a strategy to cope with and manage the behaviour of learners in school. This measure should be implemented by schools that experience excessive behavioural problems. Training in classroom management and coping with learners' undisciplined behaviour should be included in the curriculum for teacher training and followed up by regular in-service training.

More than $50 \%$ of the participants indicated that they would prefer to use corporal punishment as a disciplinary measure in extreme cases, and it is suggested that this preference should be investigated. The debate on this issue has not yet been settled.

In conclusion, the role played by learners themselves should not be underestimated. A culture of accepting responsibility for one's own behaviour and an emphasis on the teaching of norms and values are in line with the Christian command of authority and should form an integral part of both the school's ethos and the life-orientation curriculum.

\section{Acknowledgements Competing interests}

The authors declare that they have no financial or personal relationship(s) that may have inappropriately influenced them in writing this article.

\section{Authors' contributions}

Both authors M.W.d.W (University of South Africa) and A.C.L. (University of South Africa) contributed equally to the writing of this article.

\section{References}

Axup, T. \& Gersch, I., 2008, 'The impact of challenging student behaviour upon teachers' lives in a secondary school: Teachers' perceptions', British Journal of Special Education 35(3), 145-151.

Baron, R.M. \& Kenny, D.A., 1986, 'The moderator-mediator variable distinction in social psychological research: Conceptual, strategic, and statistical considerations', Journal of Personality and Social Psychology 51(6), 1173-1182.

Biemond, M., Van der Walt, J.L. \& Wolhuter, C.C., 2010, 'Disciplineverbetering door omvorming van de klas tot een morele gemeenschap' [Discipline improvement by transforming the classroom into a moral community]', Tydskrif vir Christelike Wetenskap, Spesiale uitgawe 1, 55-75.

Conroy, M.A., Sutherland, K.S., Snyder, A.L. \& Marsh, S., 2008, 'Class-wide interventions: Effective instruction makes a difference', Teaching Exceptional Children 40(6), 25-30.

Creswell, J.W., 2002, Educational research: Planning, conducting, and evaluating quantitative and qualitative research, Merril Prentice Hall, Upper Saddle River, NJ.

Davis, B. \& Sumara, D., 1997, 'Cognition, complexity, and teacher education', Harvard Educational Review 67(1), 105-125.

De Witt, M.W. \& Lessing, A.C., 2012, 'The voices of teachers: The influence of learners' behaviour problems on the life world of teachers', Education Association of South Africa (2011) conference proceeding, Digital Print Solutions, Cape Town, January 10-13, 2011, pp. 27-440.

Donald, D., Lazarus, S. \& Lolwana, P., 1997, Educational psychology in social context: Challenges of development, social issues, special needs in Southern Africa, Oxford University Press, Cape Town.

Ellenwood, S., 2007, 'Resisting character education: From McCuffey to narratives', Journal of Education 187(3), 20-43.

Ertesvåg, S.K. \& Vaaland, G.S., 2007, 'Prevention and reduction of behavioural problems in school: An evaluation of the respect program', Educational psychology 27(6), 713-736.

Franzen, K. \& Kamps, D., 2008, 'The utilization and effects of positive behavior support strategies on an urban school playground', Journal of Positive Behavior Interventions 10(3), 150-161.

Gall, J.P., Gall, M.D. \& Borg, W.R., 2005, Applying educational research: A practical guide, 5th edn., Pearson, New York.

Gay L.R., Mills G.E. \& Airasian, P., 2006, Educational research: Competencies for analysis and applications, 8th edn., Pearson, Upper Saddle River, NJ.

Gomez, B.J. \& Ang, P.M., 2007, 'Promoting positive youth development in schools', Theory Into Practice 46(2), 97-104.

Hastings, R.P., 2005, 'Staff in special education settings and behaviour problems: Towards a framework for research and practice', Educational Psychology 25(2/3), 207-221.

Heystek, J., 2010, 'Onderwyser-leierskap vir positiewe onderrig- en leerklimaat [Teacher leadership for positive teaching and learner climate]', Tydskrif vir Christelike Wetenskap 46, 39-55. 
Jesson, J. \& Lacey, F., 2006, 'How to do (or not to do) a critical literature review', Pharmacy Education 6(2), 139-148.

Joubert, R. \& Serakwane, J., 2009, 'Establishing discipline in the contemporary classroom', Journal of Educational Studies (8), 25-137.

Kaspereen, D., 2012, 'Relaxation intervention for stress reduction among teachers and staff', International Journal of Stress Management 19(3), 238-250.

Klusmann, U., Kunter, M., Trautwein, U., Lüdtke, O. \& Baumert, J., 2008, 'Engagement and emotional exhaustion in teachers: Does the school context make a difference?', Applied Psychology: An International Review 57, 127-151.

Lessing, A.C. \& De Witt, M.W., 2010, 'Karakterbou en christelike waardes vir die bevordering van gedissiplineerde klaskamergedrag: 'n Kritiese beskouing [Character and Christian values to promote disciplined classroom behaviour: $A$ critical review]', Tydskrif vir Christelike Wetenskap, 46, 21-37.

McMillan, J.H. \& Schumacher, S., 2006, Research in education. Evidence-based inquiry, 6 th edn., Pearson, New York.

Monama, T., 2012, 'Teacher shortage crisis affects half SA's schools', sowetanlive viewed 08 April 2013, from http://www.sowetanlive.co.za/news/2012/06/18/ teacher-shortage-crisis-affects-half-sa-s-schools

Morrisson Bennett, M.O. \& Bratton, S.C., 2011, 'The effects of child teacher relationship training on the children of focus: A pilot study', International Journal of Play Therapy 20(4), 193-207.

Oosthuizen, I. (ed.), 2006, Praktiese wenke vir leerderdissipline, Van Schaik, Pretoria.

Page, C. \& Meyer, D., 2003, Applied research design for business and management, McGraw-Hill Companies Inc, New York, NY.
Pšunder, M., 2005, 'Identification of discipline violations and its role in planning corrective and preventive discipline in school', Educational Studies 31(3), 335-345.

Reyes, M.R., Marc A., Brackett, M.A., Rivers, S.E., White, M. \& Salovey, P., 2012 'Classroom emotional climate, student engagement, and academic achievement', Journal of Educational Psychology 104(3), 700-712.

Saunders, M., Lewis, P. \& Thornhill, A., 2003, Research methods for business students, Financial Times-Prentice Hall, London.

Scarpaci, R.T., 2007, 'IOSIE: A method for analysing student behaviour problems', The Clearing House 80(3), 111-116.

Schaubman, A., Stetson, E. \& Plog, A., 2011, 'Reducing teacher stress by implementing collaborative problem solving in a school setting', School Social Work Journal 5 , 72-93.

Siltaloppia, M., Kinnunena, U. \& Feldt, T., 2009, 'Recovery experiences as moderators between psychosocial work characteristics and occupational well-being', Work \& Stress 23(4), 330-348.

South African Teachers Union (SATU), 2009, Home/Tuis, viewed 09 October 2009 from http://www.saou.co.za

Truscott, S.D., Kreskey, D., Bolling, M., Psimas, L., Graybill, E., Albritton, K. et al., 2012 'Creating consultee change: A theory-based approach to learning and behavioral change processes in school-based consultation', Consulting Psychology Journal: Practice and Research 64(1), 63-82.

Ziunhia, K., Hatziharistos, D. \& Emmanouel, K., 2003, 'Greek secondary school pupils' perceived reasons for behaving appropriately and perceived teachers' strategies to maintain discipline', Educational Review 55(3), 290-303. 